\title{
MODEL OF DEPOSIT AND LOAN OF A BANK USING SPIRAL OPTIMIZATION ALGORITHM
}

\author{
Moch Fandi Ansori ${ }^{1, a}$, Kuntjoro Adji Sidarto ${ }^{1, b}$, And Novriana \\ SUMARTI $^{1, c}$ \\ ${ }^{1}$ Department of Mathematics, Faculty of Mathematics and Natural Sciences, \\ Institut Teknologi Bandung, Jalan Ganesha 10, Bandung, 40132, Indonesia \\ ${ }^{a}$ mochfandiansori@students.itb.ac.id \\ ${ }^{b}$ sidarto@math.itb.ac.id \\ ${ }^{c}$ novriana@math.itb.ac.id
}

\begin{abstract}
Nowadays, the study of financial stability of banking is important, which is to observe the behavior of the bank in the future. In this paper, a simple model of deposit and loan of a bank is solved analytically and numerically, and then it is implemented into data of four groups of commercial banks in Indonesia based on their capitals. From the data for each group of banks, the parameters will be estimated using the Spiral Optimization Algorithm. The results show that the algorithm gives satisfactory solutions in terms of closeness between the analytical and numerical solutions. In the long run, the deposit and loan volumes will be stable at their equilibrium points which showing the good condition of the future of the banks based on current state.
\end{abstract}

Key words and Phrases: Dynamical System, Deposit and Loan, Bank Stability, Spiral Optimization

\begin{abstract}
Abstrak. Dewasa ini, penelitian tentang stabilitas keuangan bank sangatlah penting untuk mengamati perilaku bank di masa depan. Dalam penelitian ini, model sederhana simpanan dan pinjaman sebuah bank akan diselesaikan secara analitik dan numerik, dan selanjutnya model ini akan diimplementasikan pada data empat Bank Umum Kelompok Usaha (BUKU) di Indonesia. Untuk masing-masing BUKU, dilakukan estimasi parameter menggunakan Algoritma Optimisasi Spiral. Hasil menunjukkan bahwa algoritma tersebut memberikan nilai taksiran parameter yang cukup dekat antara yang menggunakan analitik dan numerik. Dalam jangka panjang volume simpanan dan pinjaman akan stabil menuju titik setimbangnya, yang menunjukkan kondisi bank di masa mendatang terbilang baik.
\end{abstract}

2000 Mathematics Subject Classification: 62P05 Received: 01-11-2018, accepted: 01-04-2019. 
Kata kunci: Sistem Dinamik, Simpanan dan Pinjaman, Stabilitas Bank, Optimisasi Spiral

\section{INTRODUCTION}

One of the functions of a bank is as financial intermediary in its environment. A bank receives funds in the form of deposits from the third parties that have surpluses and makes these deposits into loans for those who have investment proposals, so that the economy in the area is going well. If the amount of deposits is fluctuated uncontrollably or the payback of loans is very low, the financial of bank will be unstable. The allocation of funds will not run well, so that it can influence the economic growth. Moreover, if it causes financial crisis, the rescue efforts will require very high costs. So it is very important for the central bank to develop bank regulations for maintaining the financial stability.

Researchers had conducted studies in the field of banking stability. Wang et al. [1] used BMA-PVAR model to examine the relationship between asset bubble, banking stability, and economic growth from both theoretical and empirical perspectives. Jayakumar et al. [2] examined the links between banking competition, banking stability, and economic growth utilizing Vector Error-Correction model.

Meanwhile, in the study on banking crisis, Dabrowski et al. [3] applied dynamic Bayesian networks as early warning systems in banking crisis. Using bank stock returns and stock returns of bank dependent firms, Sohn and Park [4] found that the credit growth is more informative in predicting bank sector crisis than the credit-to-GDP gap.

Several studies on the deposit and loan model have been done. In [5], the model is constructed from the Monti-Klein model. By using an analogy with LotkaVolterra dynamical system, the model is constructed in [6] and improved in [7]. Sumarti et al. [8] constructed the model from the banking portfolio management. In this paper, the dynamical system in [8] is solved analytically and numerically. The model and its analytical solution are explained in section 2. In the implementation of the model, we use the Spiral Optimization Algorithm (SOA) from [9] and [10] to estimate all needed parameters, which is explained in section 3. The results are shown in section 4 and the conclusion is in section 5 .

\section{MODEL OF DEPOSIT AND LOAN OF A BANK}

In this section, we will explain a simple model for the deposit and loan of a bank. In the banks balance sheet, the written amount of deposit $(D)$ is not reduced even though some portion of its value is transformed as loans. The data of deposits has an upward trend month by month, so it is likely to follow the exponential growth. Considering that banks have limitations in accommodating deposits, there 
is a carrying capacity for the growth of deposits. Therefore, we assume the deposits follow the logistic growth model with the growth rate $a$ and the carrying capacity $K_{D}$.

$$
\frac{d D}{d t}=a D\left(1-\frac{D}{K_{D}}\right) .
$$

The written amount of deposits can decrease because frequently customers withdraw some of their money. So we also assume that there is a decreasing rate $\alpha$ in this model.

$$
\frac{d D}{d t}=a D\left(1-\frac{D}{K_{D}}\right)-\alpha D .
$$

On the other hand, banks are distributing the loan $(L)$ by taking some portion of deposits. The size of loans depends on the availability of deposits. The greater the available deposits, the greater the loans that can be distributed. The data of loans also has an upward trend, and we also consider the limitation of banks on channeling the loans, so we assume the loans follow the logistic growth model with the rate $\gamma$, and with a modifying carrying capacity. The idea of the modification is from the modified Lotka-Volterra model of the predator population by Beneski [11]. Rather than being a fixed value, as in the case of the deposit, the carrying capacity of the loans is continuously adjusted relative to the current density of the deposit.

$$
\frac{d L}{d t}=\gamma L\left(1-\frac{L}{K_{L} \frac{D}{K_{D}}}\right) .
$$

The carrying capacity of the loan is equal to $K_{L} \frac{D}{K_{D}}$ so that the value $K_{L}$ will be adjusted (up or down) relative to the current density of the deposits. For $D=K_{D}$, the value of $K_{L}$ can be in the fullest.

Given the fact that sometimes there are some non-performing loans (NPL), where the debtors are late or unable to pay their loans, this causes the written amount of loans decreases. So, there must a NPL rate $b$ in the loans model.

$$
\frac{d L}{d t}=\gamma L\left(1-\frac{L}{K_{L} \frac{D}{K_{D}}}\right)-b L .
$$

Thus, we have the dynamical system of deposit and loan of a bank as $d D / d t$ and $d L / d t$ in (1) and (2). For $D>0$, the system has two equilibrium points: $\left(K_{D}(a-\alpha) / a, 0\right)$ and $\left(K_{D}(a-\alpha) / a, K_{L}(a-\alpha)(\gamma-b) /(a \gamma)\right)$. These two points has respected eigen values $(-a+\alpha,-b+\gamma)$ and $(-a+\alpha, b-\gamma)$. The first eigen value gives stability if $a>\alpha$ and $b>\gamma$, which means that the NPL rate is greater than the growth rate $\gamma$ so the loan volumes will go to zero. The second eigen value gives stability if $a>\alpha$ and $\gamma>b$, which means both deposit and loan amounts are going to some positive values. It concludes the first equilibrium point is a saddle point and the second equilibrium point is stable. 
Let $\mathbf{x}=(a, \alpha, \gamma, b)^{T}$. The analytical solutions of (1) and (2) are

$$
\begin{aligned}
D(\mathbf{x}, t)= & \frac{D_{0} K_{D}(a-\alpha)}{D_{0} a+\left[K_{D}(a-\alpha)-D_{0} a\right] e^{(-a+\alpha) t}}, \text { where } D_{0}=D(\mathbf{x}, 0) \\
L(\mathbf{x}, t)= & \frac{P}{Q}, \text { where } \\
P= & D_{0} L_{0} K_{L} e^{(\gamma-b) t}\left[\left(a^{2}+\alpha^{2}\right)(-\gamma+b)+\left(\gamma^{2}+b^{2}\right)(a-\alpha)\right. \\
& \left.+2 a \alpha \gamma b\left(\frac{1}{a}-\frac{1}{\alpha}-\frac{1}{\gamma}+\frac{1}{b}\right)\right], L_{0}=L(\mathbf{x}, 0), \text { and } \\
& \\
Q= & L_{0} \gamma(a-\alpha)\left[D_{0} a+K_{D}(-\gamma+b)\right]+\frac{P}{L_{0}} e^{(-\gamma+b) t} \\
& +e^{(\gamma-b) t} D_{0} L_{0} a \alpha(-a+\alpha+\gamma-b) \\
& +e^{(-a+\alpha+\gamma-b) t} L_{0} \gamma(-\gamma+b)\left[D_{0} a+K_{D}(a+\alpha)\right] .
\end{aligned}
$$

We also solve the system (1) and (2) numerically in order to compare the performance of SOA in both analytical and numerical solutions. In the next section, we implement these solutions into the data, so all parameters can be determined. Note that these estimated parameters are needed for analytical and numerical solutions so the conditions of deposit and loan volumes can be depicted based on the data of existing banks in Indonesia.

\section{SPIRAL OPTIMIZATION ALGORITHM}

In Indonesia, there are four groups of banks classified by their capital. They are called BUKU (Bank Umum Kelompok Usaha) or Commercial Bank Group. BUKU 1, 2, 3, and 4, respectively, consist of the banks with capital less than 1, between 1 and 5 , between 5 and 30, and greater than 30 trillion rupiah. We get the data of deposit and loan of each group of banks by private conversation with Iman Gunadi, Deputy Director of Central Bank of Indonesia. The data is in term of trillion rupiah per month, taken from January 2010 until February 2015. Here, we assume January 2010 to be the initial time.

For each group of banks, we will estimate the six parameter $a, \alpha, \gamma, b, K_{D}$, and $K_{L}$. We do not estimate the value of $K_{D}$ and $K_{L}$ using SOA, because the value of $a, \alpha, \gamma$, and $b$ are so small, while the value of $K_{D}$ and $K_{L}$ are so large, so this would complicate the SOA process if we estimate the six parameters together.

First, we estimate $K_{D}$ and $K_{L}$ using the method in [12]. Rozema used three equally spaced data points to find the carrying capacity $K$ from the logistic function $y(t)=\frac{K}{1+A \exp (-g t)}$, where $g$ is its growth rate. Let $h$ be the spacing between the points and denote the points by $\left(t_{2}-h, y_{1}\right),\left(t_{2}, y_{2}\right)$, and $\left(t_{2}+h, y_{3}\right)$. Then, by substituting these points into the logistic function and solving it using some algebra, 
the value of $K$ is obtained as follows

$$
K=\frac{y_{2}\left(y_{1} y_{2}+y_{2} y_{3}-2 y_{3} y_{1}\right)}{y_{2}^{2}-y_{1} y_{3}} .
$$

Using formula (3), we can get the values of $K_{D}$ and $K_{L}$ from the data of deposits and loans. Note that, formula (3) is used to find the carrying capacity from the original logistic function. On the other hand, our model (1) and (2) are added with the decreasing rate $\alpha D$ and $b L$ resulting relatively lower values. So, the obtained value of $K_{D}$ and $K_{L}$ from formula (3) are the upper bound of the carrying capacity of model (1) and (2).

Using various values of $t_{2}$ and $h$, we obtain the parameters $K_{D}$ and $K_{L}$ of each BUKU which are presented in Table 1.

TABle 1. Parameter $K_{D}$ and $K_{L}$

\begin{tabular}{|c|c|c|c|c|}
\hline BUKU & $t_{2}$ & $h$ & $K_{D}$ & $K_{L}$ \\
\hline 1 & 31 & 30 & 207.1584 & 229.6587 \\
2 & 30 & 29 & 1136.5636 & 1384.8330 \\
3 & 30 & 29 & 1567.7830 & 1465.2140 \\
4 & 29 & 26 & 5260.5490 & 5034.9496 \\
\hline
\end{tabular}

Next, the parameter $\mathbf{x}=(a, \alpha, \gamma, b)^{T}$ will be estimated by using Spiral Optimization Algorithm (SOA) developed by Tamura and Yasuda in [9]. In this paper, we propose two methods.

- Method 1. Minimizing the errors between the analytical solution and the data.

- Method 2. Minimizing the errors between the Runge-Kutta approximation solution of the system and the real data.

Consider the analytical solution $D\left(\mathbf{x}, t_{j}\right)$ and $L\left(\mathbf{x}, t_{j}\right)$, and the real data $D\left(t_{j}\right)$ and $L\left(t_{j}\right)$, where $t_{j}=(j-1) / 12$ is time in term of month, $j=1,2, \ldots, l$, and $l$ is the number of data. We use Mean Absolute Percentage Error (MAPE) as the objective function for the minimization problem as follows,

$$
f(\mathbf{x})=\frac{1}{2} \frac{100 \%}{l} \sum_{j=1}^{l}\left(\left|\frac{D\left(t_{j}\right)-D\left(\mathbf{x}, t_{j}\right)}{D\left(t_{j}\right)}\right|+\left|\frac{L\left(t_{j}\right)-L\left(\mathbf{x}, t_{j}\right)}{L\left(t_{j}\right)}\right|\right) .
$$

We choose MAPE as the objective function due to no existence of unit, so they are in percentage. One can use Mean Squared Error as the objective function, or other error methods.

The SOA for Method 1 for minimizing $f(\mathbf{x})$ in (4) is developed below. Notice that, in the first step of SOA in the algorithm below, instead of using pseudorandom numbers for the initial points as in [9], we use Sobol squences proposed by Sidarto and Kania [10]. Let $S_{4}(r, \theta)=r R^{(4)}$, where $R^{(4)}=\prod_{i=1}^{3}\left(\Pi_{j=1}^{i} R_{4-i, 5-j}^{(4)}\right)$ and $r$ is scale of the rotation of the matrices. $R_{i, j}^{(4)}$ is $4 \times 4$ matrix whose entries 
follows. $r_{i i}=r_{j j}=\cos \theta, r_{j i}=\sin \theta, r_{i j}=-\sin \theta$ and $r_{s t}=\delta_{s t}$ for all other entries of $R_{i, j}^{(4)}$, where $\delta_{s t}=1$ if $s=t$ and $\delta_{s t}=0$ if $s \neq t$.

Input :

$m(\geq 2)$ the number of search points

$\theta(0<\theta<2 \pi), r(0<r<1)$

$k_{\text {max }}$ maximum number of iterations

Process :

Step 1. Generate Sobol sequence initial points $\mathbf{x}_{i}(0) \in \mathbb{R}^{4}$, $i=1,2, \ldots, m$, in the feasible region $I$,

where $\mathbf{x}_{i}(0)=\left(a_{i}(0), \alpha_{i}(0), \gamma_{i}(0), b_{i}(0)\right)^{T}$.

Step 2. Set $k=0$.

Step 3. Find $\mathbf{x}^{*}$ as $\mathbf{x}^{*}=\mathbf{x}_{i_{g}}(0)$ with $i_{g}=\arg \min f\left(\mathbf{x}_{i}(0)\right)$, $i=1,2, \ldots, m$

Step 4. Update $\mathrm{x}_{i}$ : $\mathbf{x}_{i}(k+1)=S_{4}(r, \theta) \mathbf{x}_{i}(k)-\left(S_{4}(r, \theta)-I_{4}\right) \mathbf{x}^{*}, i=1,2, \ldots, m$ where $\mathbf{x}_{i}(k)=\left(a_{i}(k), \alpha_{i}(k), \gamma_{i}(k), b_{i}(k)\right)^{T}$

Step 5. Update $\mathrm{x}^{*}$ : $\mathbf{x}^{*}=\mathbf{x}_{i_{g}}(k+1)$ with $i_{g}=\underset{i}{\arg \min } f\left(\mathbf{x}_{i}(k+1)\right)$, $i=1,2, \ldots, m$

Step 6. If $k=k_{\max }$ then stop.

Otherwise, set $k=k+1$ and return to step 4 .

\section{Output :}

$\mathbf{x}^{*}$ as a minimum point of $f(\mathbf{x})$.

Therefore, $\mathbf{x}^{*}=\left(a^{*}, \alpha^{*}, \gamma^{*}, b^{*}\right)^{T}$ is the parameters vector of model (1) and (2).

In solving the system (1) and (2) numerically for method 2, the points that have been spread in region $I$ in the first step of SOA are substituted as the value of parameters into the system (1) and (2). Then, we solve it using Runge-Kutta $(4,5)$ formula to get the approximation of the solutions of the system, namely $\hat{D}\left(\mathbf{x}, t_{j}\right)$ and $\hat{L}\left(\mathbf{x}, t_{j}\right)$. The SOA for Method 2 is similar to the previous algorithm, except in Step 3 and Step 5, where the objective function $f(\mathbf{x})$ being used is

$$
f(\mathbf{x})=\frac{1}{2} \frac{100 \%}{l} \sum_{j=1}^{l}\left(\left|\frac{D\left(t_{j}\right)-\hat{D}\left(\mathbf{x}, t_{j}\right)}{D\left(t_{j}\right)}\right|+\left|\frac{L\left(t_{j}\right)-\hat{L}\left(\mathbf{x}, t_{j}\right)}{L\left(t_{j}\right)}\right|\right) .
$$

\section{NUMERICAL RESULTS}

All numerical experiments in this study were performed in Matlab R2017a software on a computer equipped with processor Intel Core ${ }^{T \mathrm{M}} \mathrm{i} 5-4590$ with 4 GB ram and $3.3 \mathrm{GHz}$ CPU running Windows 10.

The input of SOA for Method 1 and Method 2 are given in Table 2 and the proposed methods give results in Table 3. The average time for running Method 
TABLE 2. Parameter values of SOA

\begin{tabular}{|c|c|c|c|c|c|}
\hline BUKU & $m$ & $k_{\max }$ & $\theta$ & $r$ & $I$ \\
\hline 1 & 500 & 100 & $\pi / 4$ & 0.95 & {$[0,2]^{4} \subset \mathbb{R}^{4}$} \\
2 & 500 & 100 & $\pi / 4$ & 0.95 & {$[0,1]^{4} \subset \mathbb{R}^{4}$} \\
3 & 500 & 100 & $\pi / 4$ & 0.95 & {$[0,4]^{4} \subset \mathbb{R}^{4}$} \\
4 & 500 & 100 & $\pi / 4$ & 0.95 & {$[0,1]^{4} \subset \mathbb{R}^{4}$} \\
\hline
\end{tabular}

1 is $3.85 \mathrm{~s}$, while Method 2 takes average time $53.52 \mathrm{~s}$. For all BUKUs, Method 2 gives the values of $a$ and $\gamma$ close to Method 1. Meanwhile, the values of $\alpha$ for both methods are quite different, so are $b$. If we look closely to the values of NPL rate $b$ for BUKU 2, 3, and 4 , then we see that they are all very small. This means that the borrowers at the big banks are able to return their loan at their maturity times.

The values of $f$ of Method 1 are always smaller than Method 2. However, they still are almost the same, and their differences are smaller than $5 \%$, where BUKU 4 has the biggest different result. Even so, in Figure 1, the plot of analytical (left) and numerical (right) solutions of system (1) and (2) for BUKU 4 are quite close to the plot of the real data. All these results tell us that SOA is powerful to be used for estimating the parameters of system (1) and (2).

TABLE 3. Results of method 1 and 2

\begin{tabular}{|c|c|c|c|c|c|c|}
\hline BUKU & Method & $a$ & $\alpha$ & $\gamma$ & $b$ & $f$ \\
\hline \multirow{2}{*}{1} & 1 & 0.450338 & 0.017582 & 1.195035 & 0.136942 & $2.2622 \%$ \\
& 2 & 0.401661 & $1.82 \mathrm{E}-05$ & 1.342291 & 0.162015 & $2.3596 \%$ \\
\hline \multirow{2}{*}{2} & 1 & 0.344706 & 0.004794 & 0.71816 & $2.01 \mathrm{E}-04$ & $1.6859 \%$ \\
& 2 & 0.355647 & 0.014328 & 0.724636 & $1.38 \mathrm{E}-05$ & $1.7023 \%$ \\
\hline \multirow{2}{*}{3} & 1 & 0.446774 & 0.010492 & 3.371426 & $1.32 \mathrm{E}-04$ & $1.5833 \%$ \\
& 2 & 0.414695 & $3.56 \mathrm{E}-05$ & 3.618335 & $4.17 \mathrm{E}-05$ & $1.7507 \%$ \\
\hline \multirow{2}{*}{4} & 1 & 0.232243 & 0.020324 & 0.717875 & $4.73 \mathrm{E}-05$ & $2.0399 \%$ \\
& 2 & 0.175286 & $2.52 \mathrm{E}-05$ & 0.799479 & $4.85 \mathrm{E}-07$ & $3.3817 \%$ \\
\hline
\end{tabular}

Table 4 shows the parameters that obtained by Sumarti et al. in [8]. In comparing Table 3 and 4, our numerical results in this paper give smaller MAPE, except for only BUKU 1 and 4 in Method 2. Thus, the method 1 gives better result than the others, which is straightforward because it uses analytical solution.

TABLE 4. Parameters from Sumarti et al. [8]

\begin{tabular}{|c|c|c|c|c|c|c|c|}
\hline BUKU & $a$ & $\alpha$ & $\gamma$ & $b$ & $K_{D}$ & $K_{L}$ & MAPE \\
\hline 1 & 0.0326 & 0.0012 & 0.1173 & 0.0181 & 236.2666 & 271.4573 & $2.6320 \%$ \\
2 & 0.0307 & 0.0022 & 0.0541 & $1.2741 \mathrm{E}-4$ & $1.1495 \mathrm{E} 3$ & $1.4912 \mathrm{E} 3$ & $3.1180 \%$ \\
3 & 0.0351 & 0.0021 & 0.1389 & $1.3832 \mathrm{E}-4$ & $1.6982 \mathrm{E} 3$ & $1.7406 \mathrm{E} 3$ & $2.3625 \%$ \\
4 & 0.0125 & $3.9910 \mathrm{E}-4$ & 0.0352 & $7.5916 \mathrm{E}-13$ & $1.4733 \mathrm{E} 4$ & $2.0441 \mathrm{E} 4$ & $2.2004 \%$ \\
\hline
\end{tabular}



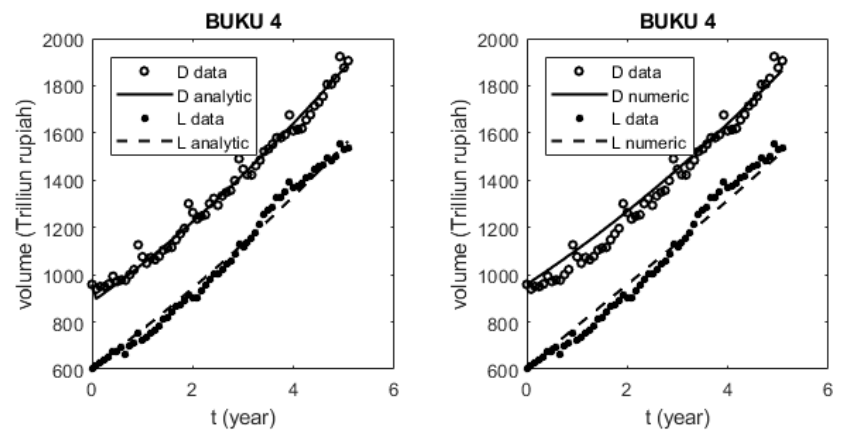

Figure 1. Plot data vs. solution of system (1)-(2) for BUKU 4

Now, we analyze the equilibrium points of dynamical system of (1)-(2), $\left(K_{D}(a-\right.$ $\alpha) / a, 0)$ and $\left(K_{D}(a-\alpha) / a, K_{L}(a-\alpha)(\gamma-b) /(a \gamma)\right)$, which have respected eigen values $(-a+\alpha,-b+\gamma)$ and $(-a+\alpha, b-\gamma)$. The results in Table 3 show that the parameters satisfying $a>\alpha$ and $\gamma>b$. Therefore, the first equilibrium point is a saddle point, while the second equilibrium point is stable. For the obtained parameters, the stable equilibrium points $\left(D^{*}, L^{*}\right)$ are given in Table 5 . Similar to the previous, BUKU 4 has the biggest different between Method 1 and Method 2.

TABLE 5. Stable equilibrium points

\begin{tabular}{|c|c|c|c|}
\hline BUKU & Method & $D^{*}$ & $L^{*}$ \\
\hline \multirow{2}{*}{1} & 1 & 199.0707 & 195.4029 \\
& 2 & 207.1490 & 201.9297 \\
\hline \multirow{2}{*}{2} & 1 & 1120.7559 & 1365.1900 \\
& 2 & 1090.7760 & 1329.0183 \\
\hline \multirow{2}{*}{3} & 1 & 1530.9372 & 1430.7228 \\
& 2 & 1567.6484 & 1465.0713 \\
\hline \multirow{2}{*}{4} & 1 & 4800.7332 & 4594.5503 \\
& 2 & 5259.7928 & 5034.2227 \\
\hline
\end{tabular}

Figure 2 presents the plot of analytical solutions for all BUKUs. In the long run, the volumes of deposit and loan are going toward $D^{*}$ and $L^{*}$. About 20 years after January 2010, the volumes of deposits and loans of BUKU 1 and 2 are starting to go toward their stable condition. While BUKU 3 and 4 reach the similar conditions about 15 and 30 years from January 2010. The equilibrium point $D^{*}$ for all BUKUs are greater than $L^{*}$, except BUKU 2.

For BUKU 2, there is a crossing between of deposit and loan graphs. This intersection occurs at $t=5.33$ or March 2015. It can be interpreted that banks in BUKU 2 are doing good job on the management of third party funds. Also, it means that banks in BUKU 2 get big profit. Banks use some portion of this profit 
as additional their core capital. This will make some of banks in BUKU 2 can upgrade to BUKU 3 classification.
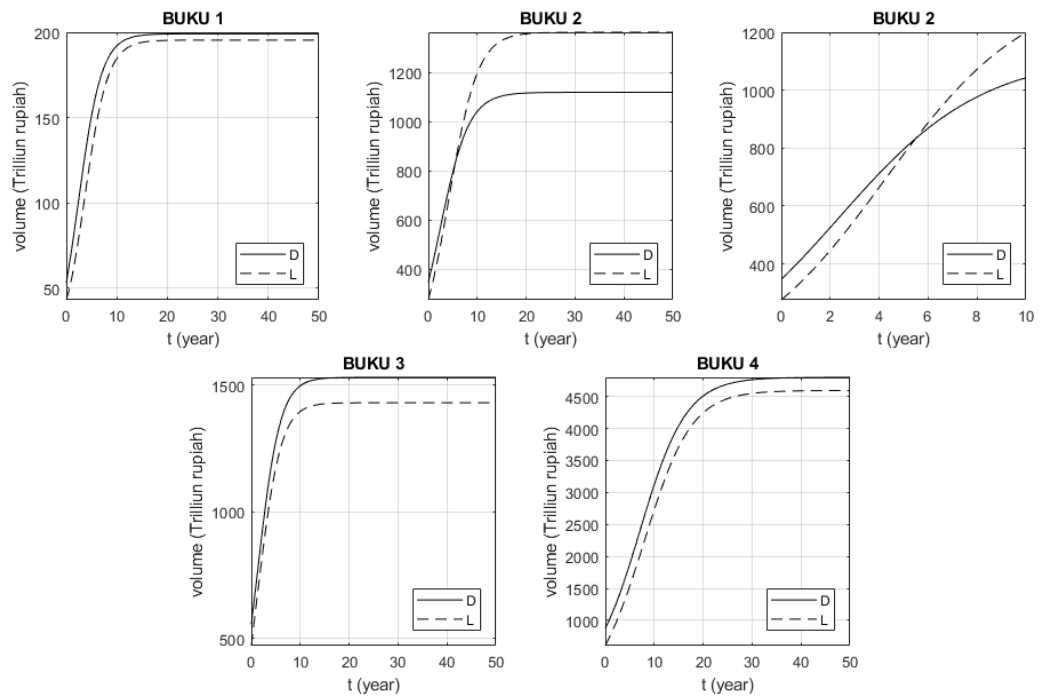

Figure 2. Plot solution of system (1)-(2)

\section{CONCLUSIONS}

The given model of deposit and loan of a bank can fit well the real data of deposit and loan of group of commercial banks in Indonesia. Using the analytical solutions of the model, Spiral Optimization Algorithm gives better results than the previous research. In the long run, between 15 or 30 years, the volumes of deposit and loan of commercial banks in Indonesia will go toward their stable equilibrium points which means they reach good stability around those years based on the existing data we used. We also conclude that some banks in BUKU 2 are predicted to upgrade into BUKU 3 classification.

\section{REFERENCES}

[1] Wang, S., Chen, L. and Xiong, X., Asset bubbles, banking stability and economic growth, Economic Modelling, (2018) https://doi.org/10.1016/j.econmod.2018.08.014.

[2] Jayakumar, M., Pradhan, R.P., Dash, S., Maradana, R.P. and Gaurav, K., Banking competition, banking stability, and economic growth: Are feedback effects at work?, Journal of Economics and Business, 96 (2018), 15-41.

[3] Dabrowski, J.J., Beyers, C. and de Villiers, J.P., Systemic banking crisis early warning systems using dynamic Bayesian networks, Expert Systems With Applications, 62 (2016), 225242 . 
[4] Sohn, B. and Park, H., Early warning indicators of banking crisis and bank related stock returns, Finance Research Letters, 18 (2016), 193-198.

[5] Sumarti, N. and Fansuri, H., "Numerical Analysis on Stability Behaviour of a Dynamical System on the Deposit and Loan of a Bank", Proc. of Int. Conf. on Computation for Science and Technology, (2014).

[6] Sumarti, N., Nurfitriyana, R. and Nurwenda, W., "A Dinamical System of Deposit and Loan Volumes based on the Lotka-Volterra Model", AIP Conference Proceedings, (2014) http://dx.doi.org/10.1063/1.4866541.

[7] Fadhlurrahman, A. and Sumarti, N., "Implementation of the dynamical system of the deposit and loan growth based on the Lotka-Volterra model and the improved model", AIP Conference Proceedings, (2016) http://dx.doi.org/10.1063/1.4945065.

[8] Sumarti, N., Fadhlurrahman, A., Widyani, H.R. and Gunadi, I., The Dynamical System of the Deposit and Loan Volumes of a Commercial Bank Containing Interbank Lending and Saving Factors, Southeast Asian Bulletin of Mathematics, 42(5) (2018), 757-772.

[9] Tamura, K. and Yasuda, K., Spiral Dynamics Inspired Optimization, J. of Advanced Computational Intelligence and Intelligence Informatics (JACIII), 15(8) (2011), 1116-1122.

[10] Sidarto, K.A. and Kania, A., Finding All Solutions of Systems of Nonlinear Equations Using Spiral Dynamics Optimization with Clusterin", J. of Advanced Computational Intelligence and Intelligence Informatics (JACIII), 19(5) (2015), 697-707.

[11] Beneski, J.T., Population Biology: Predator-Prey II, (2018) http://darwin.wcupa.edu/ beneski/projects/webplots/applets/dyno-pred-prey-ii/webx-pp.html.

[12] Rozema, E., Epidemic models for SARS and Measles, The Collage Mathematical Journal, 38(4) (2007), 246-259. 